\title{
Various methods of heat supply for a building which is operated periodically during the year
}

\author{
Marek Małetka ${ }^{1, *}$, and Marta Laska ${ }^{2}$ \\ ${ }^{1}$ Glasgow Caledonian University, School of Engineering and Built Environment, Cowcaddens Rd, \\ Glasgow G4 0BA, United Kingdom \\ ${ }^{2}$ Wroclaw University of Science and Technology, Faculty of Environmental Engineering, Wybrzeże \\ Wyspiańskiego 27, 50-370 Wrocław, Poland
}

\begin{abstract}
Stand-alone buildings operated periodically require heat supply for hot water and heating purposes to be carefully analyzed in terms of the technical capabilities, the energy and financial outlays. The paper presents the analysis of heat supply for hot water purposes and central heating in the stand-alone cloakroom building located in Poland. The analysis is undertaken for different variants of heat delivery for a building from electric heaters, gas boiler and district heating solutions to renewable sources applications, namely solar panels and heat pumps. For each solution, usage of usable, final and primary energy was calculated. Also the financial analysis for investments and energy costs were carried out. This analysis has been done in according to SPBT and NPV method for different levels of building use.
\end{abstract}

\section{Introduction}

\subsection{Domestic hot water}

Because of growth of sophisticated methods of heat obtain a slight inconvenience in system's designing process can appear. One of the fundamental problems is to term hot water demand for specific type of a building like stand-alone cloakroom. In the Polish regulations and other publications there are lacks of clear specified values of hot water demand which should be accepted for this kind of a building. The authors [1] presents the usage of domestic water in Solar City and compare it with former studies in other parts of Canada and North America. The [2] compared usage of DHW (Domestic Hot Water) in Spain, Japan, United States and China. The data for Switzerland, Hungary and Finland can be also found in [3]. However all these publications describe the research for residential buildings. Some data dedicated for stand-alone cloakroom can be found in [4-7]. However it can be seen that each author gives different data, which are set on their own experiences (Table 1).

As can be noticed in Table 1 the highest value of hot water demand is given by [4] which is much bigger than value given in polish standard [5]. Similar data can be found in

\footnotetext{
* Corresponding author: marek.maletka@gcu.ac.uk
} 
$[5,6]$. The lowest need for hot water in building used for sport activities is defined in [7] and to avoid overestimation for the following analysis this value will be taken.

Table 1. Summary of hot water demand according to various authors.

\begin{tabular}{|c|c|c|c|}
\hline \multirow{2}{*}{$\begin{array}{c}\text { Literature } \\
\text { source }\end{array}$} & $\begin{array}{c}\text { Hot water } \\
\text { demand }\end{array}$ & $\begin{array}{c}\text { Hot water } \\
\text { demand }\end{array}$ & $\begin{array}{c}\text { Hot water } \\
\text { temperature }\end{array}$ \\
\cline { 2 - 4 } l/person & ${ }^{\circ} \mathbf{C}$ \\
\hline$[4]$ & 0.167 & 50 & 45 \\
\hline$[5]$ & 0.150 & 45 & 60 \\
\hline$[6]$ & 0.133 & 40 & 60 \\
\hline$[7]$ & 0.073 & 22 & 55 \\
\hline
\end{tabular}

\subsection{Heating}

The heating system design for a building which operates constantly during the year, the calculation procedure is determined by European Standard [8] were the external design temperatures for winter period are defied. However when the periodic operation of a building with only summer and transitional period is under considerations there is no information in engineering guidelines about the value of external temperature that should be applied in calculations. Similarly, when building works under non-occupied mode and the indoor temperature is maintained on lower heating set point temperature. Therefore 3 options has been investigated under the study, however the detailed analysis of these options is not a subject of this paper. The chosen method for further heat load calculations is based on stand-by indoor temperature and the external average of the minimum temperatures in the transition period $[9,10]$.

\section{Building characteristic}

The object which is considered is a stand-alone cloakroom building located next to the football pitch. The property is located in Lower Silesia District (Poland) in the second climate zone for which design external temperature during the winter is $-18^{\circ} \mathrm{C}$. The exact values of design parameters used for calculations are described in section 3 .

The design building has an heating area of $105.7 \mathrm{~m}^{2}$. It contains of two players cloakrooms, two showers, two toilets, referees changing room, coach room, disabled WC, store and technical room. The design conditions assume usage of hot water for 32 people at one time (beak between matches). This amount assumes the presence of 15 people in each player's locker room and two referees. The cloakroom is opened from March to October, from Monday to Saturday between 8:00 a.m. and 8:00 p.m., and on Sundays from 10:00 a.m. to 7:00 p.m. Frequency of water usage is 15 minutes for each 1,5 hour.

\section{Energy investigation}

The heat demand calculation for a building for a central heating purpose was based on the European Standard PN-EN 12831:2006. Because of the periodical utilisation of the building, there is no need to maintain the indoor temperature as a comfort one during the winter season.

First operational scheme is applied for spring and fall (between March to May and from September to October). It assumes the external temperature of $-0.3^{\circ} \mathrm{C}$ [9]; the internal 
temperature is set on $20^{\circ} \mathrm{C}$ or $24^{\circ} \mathrm{C}$ depending on the room type [10]. For these assumption the design heat loss is $9601 \mathrm{~W}$.

Second operational scheme is applied for winter when the building is non-occupied. The external temperature is defined on $-18^{\circ} \mathrm{C}$. For this condition, to avoid freezing of the building installation, it is needed to provide the stand-by temperature of $5^{\circ} \mathrm{C}$. For these conditions in winter time the design heat loss equals $9019 \mathrm{~W}$. Therefore for further considerations the higher value of $9.6 \mathrm{~kW}$ was taken into account.

The paper presents different variants of heat delivery for a building, namely: Solution (Sol.) 1, Option (Opt.) 1.1 Electric hot water heaters with the local electric heating; Opt. 1.2 Electric hot water heaters with central heating; Sol. 2 Gas boiler with domestic hot water cylinder; Sol. 3 District heating substation; Sol. 4, Opt. 4.1 Flat plate solar panels, Opt. 4.2 Vacuum solar panels; Sol. 5, Opt. 5.1 Brine-to-water heat pump with horizontal ground collector, Opt. 5.2 Brine-to-water heat pump with vertical the bore holes.

\subsection{Usable energy}

The total annual demand for usable energy for the building was calculated in a basis of the Regulation of Minister of Infrastructure and Development [11]. The usable energy only for heating system equals $19006 \mathrm{kWh} / \mathrm{a}$.

The usable energy for DHW was calculated in two different ways. The first approach followed the current Regulation of the Minister of Infrastructure and Development [11] that assumes the relation of DHW demand with the heated area of the building. Following this method the value of the usable energy is $252.6 \mathrm{kWh} / \mathrm{a}$.

The second method bases on designed DHW use by the reference unit during the day. It is largely described in the previous Regulation of Minister of Infrastructure [12]. The energy value calculated by this method is $61945 \mathrm{kWh} / \mathrm{a}$.

As one can notice, the value of useable energy calculated by a hot water consumption method based on the number of people in the building [12] is significantly different than that which is contained in the current Regulation [11]. This difference is largely due by water demand and reference method. In the first case the individual requirement is $0.25 \mathrm{dm}^{3} / \mathrm{m}^{2}$ per day and the entire surface of the heated space is $105.7 \mathrm{~m}^{2}$. It gives us $26.4 \mathrm{dm}^{3}$ of daily hot water demand. Relative to the second method this value is almost similar to that used by one person during one shower. Due to the type of use of the building which is located at the sports field where usually take place team games it can be concluded that during the day more than one person will take a shower.

The second issue aroused a considerable doubt in the usable energy demand calculation in the case of rigidly specified time of the building usage which is 365 days during the year. The legislature in this case didn't foresee the possibility of changing this value which in case of periodically operated building may appear significant differences in the results. For this reason, it can be concluded that the value calculated using the water consumption related to the number of people in a building is more likely while the value obtained in the first method may greatly underestimate the final results. Therefore the following calculations are based on the second methodology.

\subsection{Final energy}

The annual demand on the final energy was calculated according to the current Regulation of Minister of Infrastructure and Development [11]. Electric power and working time for specific auxiliary equipment was estimated on the basis data contained in the Regulation. As it is impossible to define the average daily amount of DHW used by the facility users, therefore the final energy consumption has been presented in the level of DHW usage 
where $100 \%$ indicates the maximum and $0 \%$ the minimum value of DHW use. Summary of final energy demand for each solution is presented in the Fig. 1.

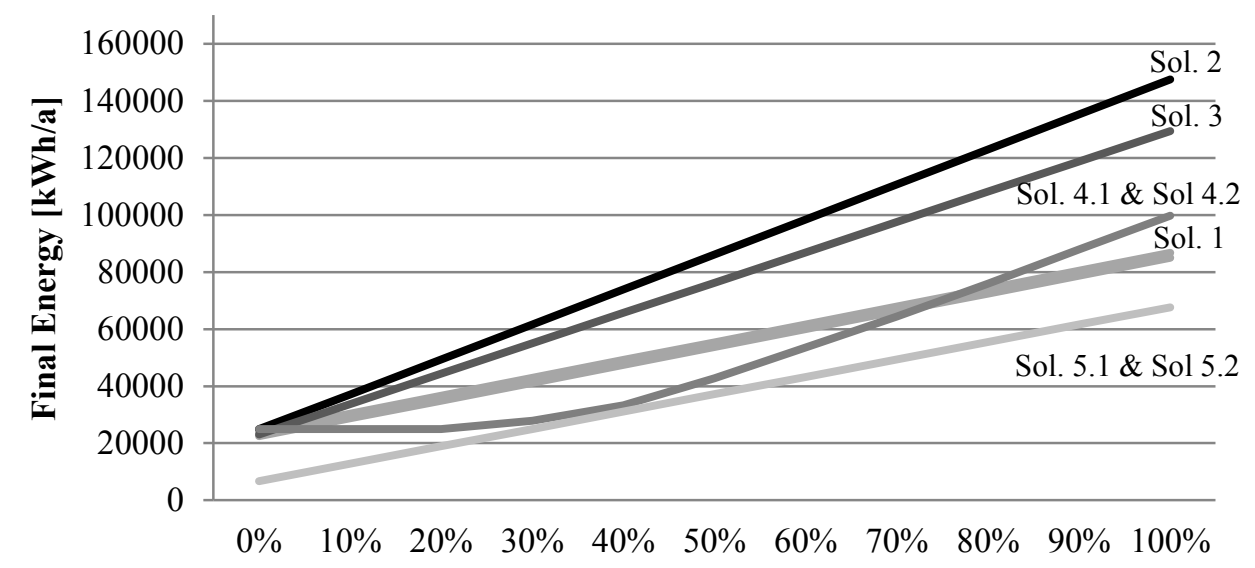

DHW installation use

Fig. 1. Final energy demand according to percentage of DHW use.

Fig. 1 shows that solution 2 uses the highest final energy for any partial DHW demand. For the largest use of DHW this value is twice higher than that for solution five - based on brine-to-water heat pump. Slightly smaller demand has the solution with district heating Sol. 3. The most interesting option in the energy point of view is solar panels (Sol. 4) where the demand for the final energy is changing in nonlinear way, namely: in the range of $0 \%-30 \%$ the final energy demand is higher only than fifth solution assuming heat pump; at $40 \%$ the final energy is comparable with Sol. 5 ; in the range of $50 \%-100 \%$ the final energy grow much faster than the demand for other solutions. What is more it reaches a greater value than electric heater for hot water use (Sol. 1), above $80 \%$.

The difference between solutions results from the efficiency of the various elements of the system like: type of the heat source, its transfer and also method of heat storage.

\subsection{Primary energy}

Demand on primary energy has been calculated following [11] for particular solution. It takes into account the primary energy factor for electricity that varies depending on the source of energy. The outcome is presented in Fig. 2.

As can be noticed on the chart (Fig. 2) the highest demand on primary energy has Sol. 1 in both options and Sol. 5. It is interesting as the solution 5 assumes usage of renewable, highly efficient energy source. The heat pump converts electrical energy and therefore, according the [11], the value of 'effort coefficient' is the same as for any other electrical device. At the same time the heat pump solution characterizes the lowest demand on the final energy and thus the lowest operating costs.

According to the above chart the least impact on the environment has third solution based on a district heating network. Sol. 3 generates less than half of primary energy comparing the worst one - Sol. 1 and 5 . 


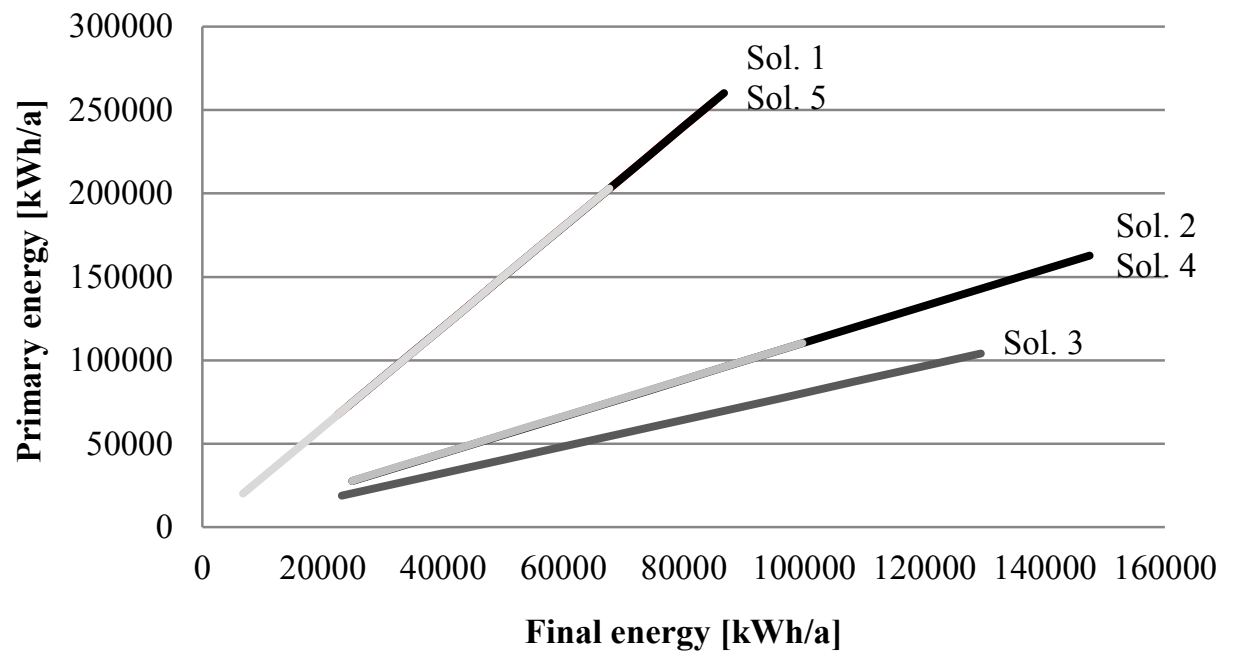

Fig. 2. Annual primary energy demand according to final energy.

\section{Financial analysis}

\subsection{Investment cost}

For each solution the investment costs based on prices in Polish Zloty (PLN) valid for 2016 were calculated (The average exchange rate is $1 \mathrm{PLN}=\$ 0.259$ ). The summary is presented in Table 2.

Table 2. Investment costs.

\begin{tabular}{|c|c|c|c|c|c|c|c|}
\hline \multicolumn{2}{|c|}{ Sol. 1 } & \multirow{2}{*}{ Sol. 2 } & \multirow{2}{*}{ Sol. 3 } & \multicolumn{2}{c|}{ Sol. 4 } & \multicolumn{2}{c|}{ Sol. 5 } \\
\cline { 5 - 8 } Opt. 1.1 & Opt. 1.2 & & & Opt. 4.1 & Opt. 4.2 & Opt. 5.1 & Opt. 5.2 \\
\hline PLN & PLN & PLN & PLN & PLN & PLN & PLN & PLN \\
\hline 57157 & 46043 & 33824 & 34161 & 91970 & 133286 & 115208 & 135640 \\
\hline
\end{tabular}

\subsection{Operating cost}

Annual operating costs for each solution were calculated for final energy values and energy tariffs for electricity, gas, and district network heat, established by polish companies. All the tariffs are valid for December 2016. The calculation outcome is presented at Fig. 3.

The highest operating cost generate solutions based on electric hot water heaters (Sol. 1) Little less cost has district heating (Sol. 3) and gas boiler (Sol. 2). The most advantageous from the operating costs point of view is utilization of heat pumps.

The Fig. 4 shows price of $1 \mathrm{kWh}$ for each analysed solution according to DHW use. The lowest and almost constant prices generate solutions with gas boiler, solar panel and heat pump (solution 2, 4 and 5). The $1 \mathrm{kWh}$ price varies in a nonlinear way. All the solutions except electric heaters are characterized by minor differences with high DHW use. For solution one with low DHW use $1 \mathrm{kWh}$ price is almost three times higher. It's caused by high fixed fees for this solution. This difference is changing a little with increasing of DHW 
use. Change of $1 \mathrm{kWh}$ price for each solution is generally connected with fixed fees which user has to carry on despite the lack of DHW use.

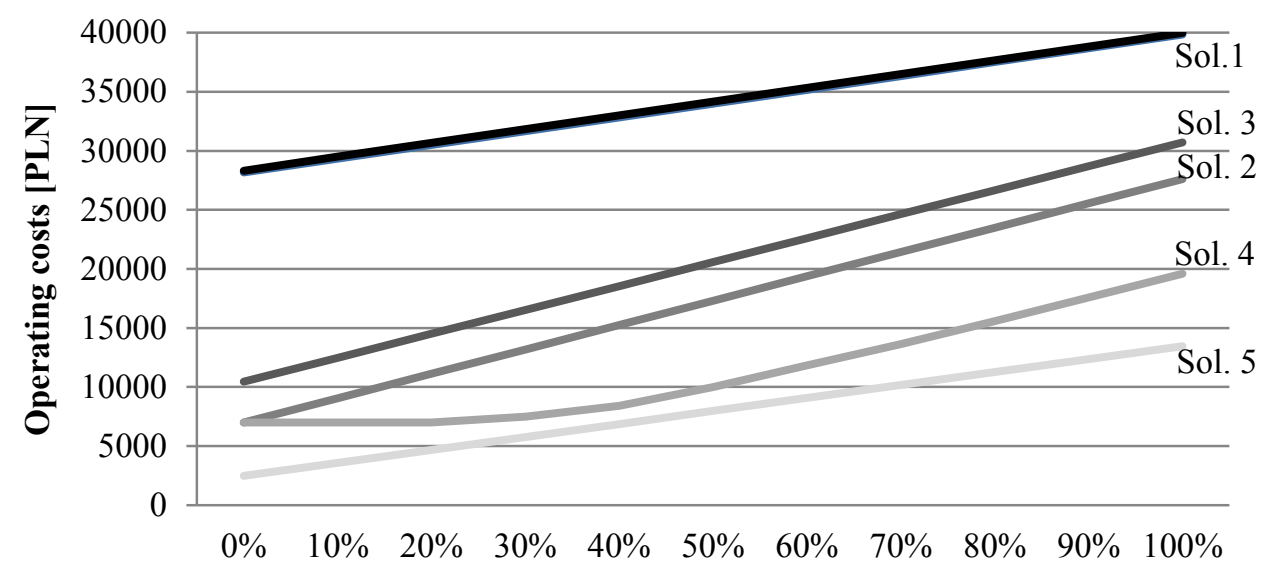

DHW installation use

Fig. 3. Operating costs according to DHW use.

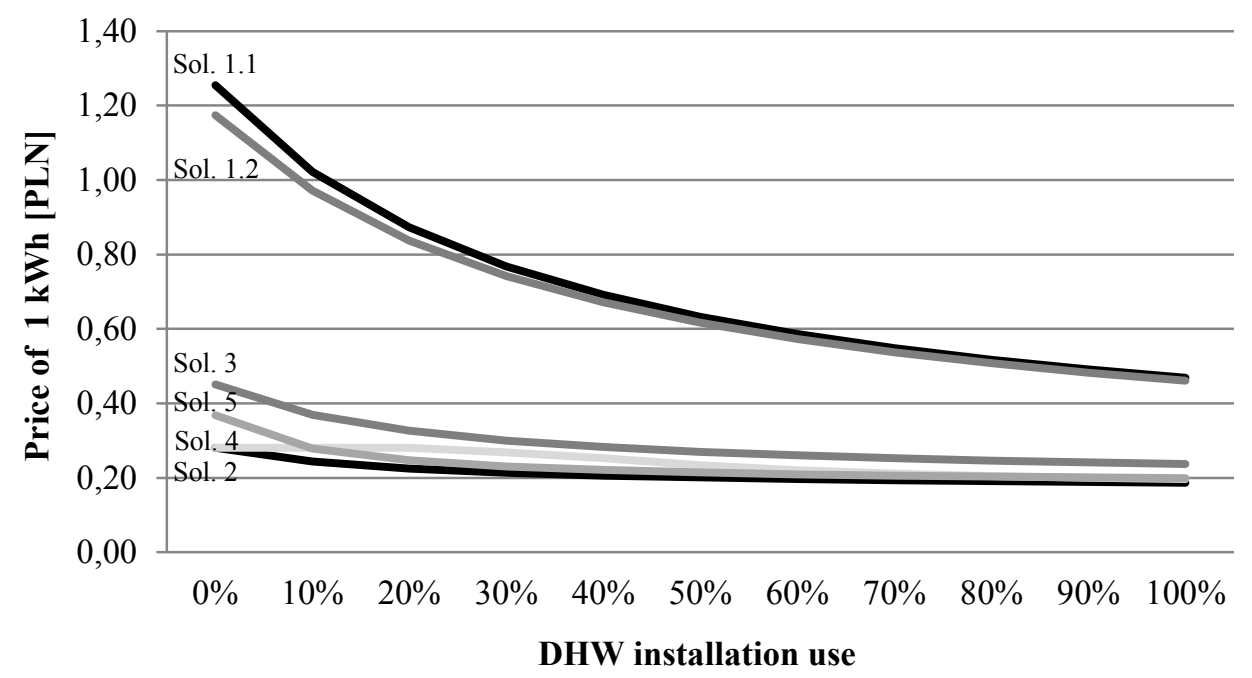

Fig. 4. Price of $1 \mathrm{kWh}$ according to DHW use.

\subsection{SPBT and NPV calculations}

To determine the economic efficiency of particular solutions Simply Pay Back Time (SPBT) and Net Present Value (NPV) were calculated. All the calculations relate to the cheapest solutions from investment point of view, namely Sol. 2. The discount rate was determined based on the average inflation rate since 2001 given by the National Polish Bank.

SPBT value depends generally on the DHW use and it decreases with increasing use. As can be seen on the Table 3 the investment cost of the first and third solutions will never payback compared to Sol. 2. Solutions with solar panels and heat pump have specified 
payback time. Both options of the fifth solution achieve rational payback time $(<15$ years) at $30 \%$ of DHW use. For Sol.4 this payback time is reached at $40 \%$ of DHW use and higher.

Table 3. SPBT value according to the cheapest solution - Sol. 2.

\begin{tabular}{|c|c|c|c|c|c|c|c|c|c|c|c|c|}
\hline \multirow{2}{*}{ Solution } & \multicolumn{10}{|c|}{ SPBT } \\
\cline { 2 - 14 } & $0 \%$ & $10 \%$ & $20 \%$ & $30 \%$ & $40 \%$ & $50 \%$ & $60 \%$ & $70 \%$ & $80 \%$ & $90 \%$ & $100 \%$ \\
\cline { 2 - 13 } & year & year & year & year & year & year & year & year & year & year & year \\
\hline \multirow{3}{*}{ Sol. 1 } & Opt.1.1 & - & - & - & - & - & - & - & - & - & - & - \\
\cline { 2 - 13 } & Opt.1.2 & - & - & - & - & - & - & - & - & - & - & - \\
\hline \multirow{2}{*}{ Sol. 3 } & - & - & - & - & - & - & - & - & - & - & - & - \\
\hline \multirow{3}{*}{ Sol. 4 } & Opt.4.1 & - & 28.2 & 14.1 & 10.2 & 8.5 & 8.0 & 7.7 & 7.5 & 7.4 & 7.3 & 7.2 \\
\cline { 2 - 13 } & Opt.4.2 & - & 48.3 & 24.1 & 17.5 & 14.5 & 13.6 & 13.2 & 12.8 & 12.6 & 12.5 & 12.4 \\
\hline \multirow{3}{*}{ Sol. 5 } & Opt.5.1 & 18.0 & 14.9 & 12.6 & 11.0 & 9.7 & 8.7 & 7.9 & 7.2 & 6.7 & 6.2 & 5.7 \\
\cline { 2 - 13 } & Opt.5.2 & 22.6 & 18.6 & 15.8 & 13.7 & 12.2 & 10.9 & 9.9 & 9.0 & 8.3 & 7.7 & 7.2 \\
\hline
\end{tabular}

The most interesting is comparison between flat solar panels (Sol. 4, Opt. 4.1) and heat pump with horizontal ground collector (Sol. 5, Opt. 5.1). For the DHW use lower than $30 \%$ heat pump is more profitable than solar panels. This situation is changing for when DHW use is between $30 \%-60 \%$ then solar panels are more profitable. For $60 \%$ the payback value is more or less equal and for more than $70 \%$ heat pump is again more profitable.

Summarizing for low and very high DHW demand solution with heat pump is the most reasonable, but when the water use is more centred solar panels is better option.

Table 4. NPV value after15 years of building use.

\begin{tabular}{|c|c|c|c|c|c|c|c|c|c|c|c|c|}
\hline \multirow{2}{*}{ Solution } & \multicolumn{10}{|c|}{ NPV } \\
\cline { 3 - 14 } & $0 \%$ & $10 \%$ & $20 \%$ & $30 \%$ & $40 \%$ & $50 \%$ & $60 \%$ & $70 \%$ & $80 \%$ & $90 \%$ & $100 \%$ \\
\cline { 2 - 13 } & PLN & PLN & PLN & PLN & PLN & PLN & PLN & PLN & PLN & PLN & PLN \\
\hline \multirow{2}{*}{ Sol. 1 } & Opt.1.1 & - & - & - & - & - & - & - & - & - & - & - \\
\cline { 2 - 13 } & Opt.1.2 & - & - & - & - & - & - & - & - & - & - & - \\
\hline \multicolumn{2}{|c|}{ Sol.3 } & - & - & - & - & - & - & - & - & - & - & - \\
\hline \multirow{2}{*}{ Sol.4 } & Opt.4.1 & - & - & - & 11225 & 25295 & 31065 & 33817 & 36821 & 38315 & 39056 & 39796 \\
\cline { 2 - 13 } & Opt.4.2 & - & - & - & - & - & - & - & - & - & - & - \\
\hline \multirow{3}{*}{ Sol.5 } & Opt.5.1 & - & - & - & 8991 & 20759 & 32526 & 44294 & 56061 & 67828 & 79596 & 91363 \\
\cline { 2 - 13 } & Opt.5.2 & - & - & - & - & 327 & 12094 & 23862 & 35629 & 47396 & 59164 & 70931 \\
\hline
\end{tabular}

According to NPV Sol. 1, 3 and Opt. 4.2 is not profitable compared to gas boiler for period of 15 years in any DHW use level and it will never pay-back. Only solutions with heat pump (Sol. 5) and planar solar panels (Sol. 1, Opt. 1.1) achieve positive values for $2.7 \%$ of discount rates after considering working time. However those profits are reachable only when DHW use level is more than $30 \%$ or $40 \%$ in case of heat pump system with vertical bore holes. It is caused definitely higher investment costs. 


\section{Conclusions}

The paper presented the analysis of heat supply for stand-alone cloak room building. Different option of heat delivery has been investigated in terms of usage, final and primary energy demand together with financial analysis based on SPBT and NPV methods.

As it was mentioned at the beginning of the analysis there are certain difficulties in designing the heat source in these types of buildings. These difficulties are caused by a lack of accurate values of hot water consumption when given available literature values are divergent. Regarding heating, there is lack of a clearly defined procedure and design values for buildings operating only during summer and transitional period.

Also energy calculations are somehow difficult as the current Polish regulations refer the energy usage for DHW purposes to the heated area of the building.

Therefore to reflect the reasonable energy usage and heat demand, and thus to calculate costs and profitability of chosen solution in such buildings the individual analysis as presented in the paper should be carried out. However even then it is not easy to determine the superiority of one solution over another.

\section{References}

1. J.C. Evarts, L.G. Swan, Energ. Buildings, 58 (2013)

2. L. Zhang, J. Xia, J.E. Thorsen, O. Gudmundsson, H. Li, S. Svendsen, Energy, 116 (2016)

3. J. de Santiago, O. Rodriguez-Vialon, B. Sicre, Predictions, Energ. Buildings (to be published, http://dx.doi.org/10.1016/j.enbuild.2017.02.045)

4. H. Recknagel, E.-R. Schramek, Compendium of Heating, Air-conditioning, Domestic Hot Water, Refrigeration (Omni Scal, Wrocław, 2008) (in Polish)

5. PN-92/B-01706 Domestic water installations - Design requirements

6. Vaillant, Designer's guide (in Polish)

7. S. Mańkowski, DHW system design (Arkady, Warszawa, 1981) (in Polish)

8. PN-EN 12831:2006 Heating systems in buildings - Method for calculation of the heat load (in Polish)

9. Polish Ministry of Infrastructure and Civil Engineering - Typical meteorological years and statistical climatic data for building energy calculations (in Polish) (http://mib.gov.pl)

10. Rozporządzenie Ministra Infrastruktury z dnia 12 kwietnia 2002 w sprawie warunków technicznych, jakim powinny odpowiadać budynki i ich usytuowanie (z późn. zmianami) (Dz.U. z 2015 poz. 1422, Warszawa, 2015)

11. Rozporządzenie Ministra Infrastruktury i Rozwoju z dnia 27 lutego 2015 w sprawie metodologii obliczania charakterystyki energetycznej budynku lub części budynku oraz świadectw charakterystyki energetycznej (Dz. U. z 2013 r. poz. 1409, Warszawa, 2015)

12. Rozporządzenie Ministra Infrastruktury $\mathrm{z}$ dnia 6 listopada 2008 r. w sprawie metodologii obliczania charakterystyki energetycznej budynku i lokalu mieszkalnego lub części budynku stanowiącej całość techniczno-użytkową oraz sposobu sporządzania wzorów świadectw charakterystyki energetycznej (Dz. U. z 2006 r. poz. 1118,Warszawa, 2008) 